\title{
RADEK ČERNOCH
}

Faculty of Law, Masaryk University, Brno, Czech Republic

\section{THE FALCIDIAN PORTION ON THE TERRITORY OF THE CZECH REPUBLIC ${ }^{*}$}

\section{INTRODUCTION}

Many institutions of present legal systems are rooted in the legal system of ancient Rome. Considering that over 2,000 years have passed since the demise of Republican Rome, it is understandable that individual institutions have undergone a specific evolution. As a result, nowadays they may resemble their Roman source only partially. On the other hand, in some cases, even nowadays we can observe a conspicuous concordance of selected legal provisions with Roman law.

The enactment of a new Civil Code ${ }^{1}$ in the Czech Republic, which came in force on $1^{\text {st }}$ January 2014, is undoubtedly an impulse to research the development of individual institutions in the Code, because many of them were not embodied in the previous Code (which is sometimes called the "Socialist Code"). ${ }^{2}$ One of them is the

* This article is a product created under Project MUNI/A/0824/2012 Military Testament in the Light of Codification of Justinian.

1 Law No. 89/2012 Sb., občanský zákoník (hereinafter referred to as "the Civil Code of 2012"). Unless otherwise stated, Czech and Czechoslovakian laws are cited according to: ASPI [database]. Version 2013. Wolters Kluwer, 2013. English translation by the author with the contribution of Mgr. Alexandra Stachurová.

2 Law No. 40/1964 Sb., občanský zákoník (hereinafter referred to as "the Civil Code of 1964"). 
Falcidian portion (quarta Falcidia). The aim of this article is thus to examine the embodiment of the Falcidian law on Czech territory from the enactment of the $\mathrm{ABGB}^{3}$ to the Civil Code of 2012.

Even though the article is focused primarily on the development of the Falcidian portion on the territory of the contemporary Czech Republic, its fundamental aim is to present a particular example demonstrating the intricate development a Roman law has followed to the present times. This might be beneficial even for a foreign reader who is not interested in the legal system of the Czech Republic. Hence the article draws chiefly from publications in foreign languages, although of course - particularly in passages relating to the Czech and Czechoslovak legal system - more detailed information can be found in the Czech literature.

\section{AnCIENT Rome}

Initially, Roman law did not restrict a testator's capacity to use institutions of universal (testamentum) as well as singular (legata) succession in any way he pleased. In universal succession the heir (heres) was absolutely liable for inheritance debts, ${ }^{4}$ while a legatee (legatarius) was not. Therefore, a decedent's estate could have been overburdened with legacies, and an acceptance of inheritance would not have been advantageous for the heir. However, this would have led to the thwarting of the legacies, because their implementation depended on the implementation of the decedent's estate. ${ }^{5}$

3 Law. No. 946/1811 Sb. z. s., Allgemeines Bürgerliches Gesetzbuch (hereinafter referred to as "ABGB”).Cited after F. RoučEK, J. SEDLÁčEK et al., Komentář k československému obecnému zákoníku občanskému a občanské právo platné na Slovensku a v Podkarparpatské Rusi. Díl třetí. (\$\$ 531 až 858). Reprint pưvodního vydání, Praha 1998, p. 680. Note: The ABGB was in force on Czechoslovakian territory till the passage of the Civil Code of 1950 (and partially till 1965). Although its text was translated into Czech, its official wording was still in German.

4 A. Borkowski, P. DU Plessis, Textbook on Roman Law ${ }^{3}$, Oxford \& New York 2005, p. 229.

5 Ibidem, p. 231. 
On that account, attempts were made to restrict the testator's possibility to overburden the estate with legacies. The first two laws (lex Furia and lex Voconia $)^{6}$ were not very efficient. The real turning point was the lex Falcidia de legatis, enacted in $40 \mathrm{BC}$. It determined that at least a quarter of the net inheritance (the Falcidian portion, quarta Falcidia), had to be reserved for the heir. ${ }^{7}$ This restriction proved to be efficient, so it was extended to other institutions that led to the acquisition of property mortis causa - trusts (fideicomissa) by SC Pegasianum ${ }^{8}$ and Antoninus Pius, and deathbed gifts (mortis causa donationes) by Septimius Severus. ${ }^{9}$

If what the testator assigned for the Falcidian portion fell short of the statutory one-quarter of the estate, the legacies were proportionally reduced to preserve the Falcidian portion. ${ }^{10}$ But the testator was free to prohibit the reduction of a certain legacy, which meant that the others would be reduced even more, to preserve the Falcidian portion even in such a case. Under Justinian, it was also determined that the Falcidian portion would not be used if an inheritor did not apply for a benefit of inventory (beneficium inventarii). Moreover, a testator could order the waiving of the Falcidian portion. ${ }^{11}$ Finally, it is necessary to add that the restriction within the meaning of "Falcidian portion" did not

6 D. SchanBacher, Ratio legis Falcidiae. Die falzidische Rechnung bei Zusammentreffen mehrerer Erbschaften in einer Hand. Berlin 1995, p. 25.

7 G. 2,227: Lata est itaque lex Falcidia, qua cautum est, ne plus ei legare liceat quam dodrantem: itaque necesse est, ut heres quartam partem hereditatis habeat: et hoc nunc iure utimur (my emphasis, R.Č.). [And so the Falcidian Act was passed. This made it unlawful for him to give legacies of more than nine-twelfths, and so the heir must necessarily have a quarter share of the inheritance. This is now the law.] (emphasis omitted). Gai Inst. cited after Gaius, Institutionum commentarii quattuor, transl. W.M. Gordon, O.F. Robinson, The Institutes of Gaius, Reprinted London, 2001, p. 579.

8 F. Longchamps de BérIer, Law of Succession. Roman Legal Framework and Comparative Law Perspective, Warszawa 2011, p. 208.

9 Ibidem, p. 142.

10 Ibidem, p. 141.

11 A. Borkowski, P. DU Plessis, op. cit., p. 234. 
apply to soldiers, ${ }^{12}$ because - within the framework of their extensive privileges in the law of succession - they could give and bequeath ... quomodo velint vel quomodo possint... ${ }^{13}$

\section{The Habsburg Empire}

Roman law passed into medieval and modern legal systems thanks to a process of reception. A major landmark in this respect in the Holy Roman Empire was the foundation of the Imperial Chamber Court (Reichskammergericht) in 1495, which was primarily intended to rule on the grounds of the law of the Empire (nach des Reiches gemeinen Recht), i.e. Roman law, and only subsequently take the local legislation into consideration. ${ }^{14}$ The Falcidian portion was a component of this legal system based on Roman law. When the first civil codes began to emerge in the Holy Roman Empire the Falcidian portion entered only some of them. ${ }^{15}$

In relation to the territory of the contemporary Czech Republic, the most important civil code was the ABGB, inspired by Roman law to a considerable extent. Its regulation of the law of succession is very extensive and legacies are given a considerable amount of attention.

12 F. LongChamps de BÉRIER, op. cit., p. 179.

13 G. 2,114: Igitur si quaeramus, an ualeat testamentum, inprimis aduertere debemus, an is, qui id fecerit, habuerit testamenti factionem: deinde si habuerit, requiremus, an secundum iuris ciuilis regulam testatus sit, exceptis militibus, quibus propter nimiam inperitiam, ut diximus, quomodo uelint uel quomodo possint, permittitur testamentum facere (my emphasis, R.Č.). [And so, if we are asking whether a will is valid, we must first of all consider whether the person who made it had the capacity to make a will; if he did we next inquire whether he followed the rules of the state law, except in the case of soldiers, who, as we have said, are allowed to make a will in any way they do and can, because they know little of such matters].

14 G. KöBLER, Lexikon der europäischen Rechtsgeschichte. München 1997, p. 488.

15 For an overview of the legal regulation in the German-speaking countries (including Austria and Switzerland) see M. HenNig, Die lex Falcidia und das Erbrecht des BGB. Eine kritische Würdigung der Entscheidung des historischen Gesetzgebers, das Rechtsinstitut der falcidischen Quart aufzugeben. Berlin 1999, p. 36 ff. 
Although the Falcidian portion was included in one of its drafts (Codex Theresianus, 1767), it did not became part of the final text, ${ }^{16}$ which meant that legacies could deplete an inheritance completely. ${ }^{17}$ But if the legacies exceeded the value of the inheritance, they were proportionally reduced. ${ }^{18}$ This reduction was performed in a manner similar to the Falcidian portion, but with a very important difference neither the quarter nor any other part of the estate was reserved for the heir. ${ }^{19}$ It is also necessary to mention that this principle applied only in the event of an unreserved inheritance application, because an heir could restrict his liability for inheritance debts and legacies within the manner of beneficium inventarii. ${ }^{20}$

16 Ibidem, p. 40.

17 Recht des Erben, wenn die Lasten die Masse erschöpfen; § 690 ABGB: Wenn die ganze Erbschaft durch Vermächtnisse erschöpft ist; so hat der Erbe nichts weiter, als die Vergütung seiner zum Besten der Masse gemachten Auslagen und eine seinen Bemühungen angemessene Belohnung zu fordern. Will er den Nachlaß nicht selbst verwalten; so muß er um die Aufstellung eines Kurators anlangen (my emphasis, R.C.). [Law of heir if burdens deplete the estate; $\S 690$ ABGB: If the whole estate is depleted by legacies, the heir cannot demand anything else than a compensation for expenses made performed for the estate, and an adequate reward for his efforts. If he does not want to administer the inheritance himself, he has to apply for an appointment of a trustee].

18 Oder gar übersteigen. § 692 ABGB: Reicht die Verlassenschaft zur Bezahlung der Schulden, anderer pflichtmäßigen Auslagen, und zur Berichtigung aller Vermächtnisse nicht zu; so leiden die Legatare einen verhältnismäßige Abzug. Daher ist der Erbe, so lange eine solche Gefahr obwaltet, die Vermächtnisse ohne Sicherstellung zu berichtigen nicht schuldig (my emphasis, R.Č.). [Or even exceed. § 692 ABGB: If an inheritance does not suffice for the payment of the debts, other compulsory expenses and incorporation of all the legacies, a proportional deduction will be done to the legatees. Therefore the heir is not obliged to perform the legacies without securing this, as long as there is such a danger].

19 R. ČERnOCH, Falcidiánská kvarta v Řimě a domácím právním vývoji, [in:] Sborníky z doktorandského semináře katedry Dějin státu a práva Právnické fakulty MUč. 2 (2012), ed. L. VoJÁČEK, J. TAUCHEN, Ostrava 2012, s. 16.

20 R. ČERNOCH, Odkaz v Řimě a domácím právním vývoji, «Časopis pro právní vědu a praxi» 20.3/2012, p. 250. 
The development of the legal system of Prussia was significant for the law of modern Germany. In Prussia the tendency was to simplify the legislation and to restrict the influence of Roman law, which resulted in the omission of the Falcidian portion out of the draft of the code of 1751 (Corpus iuris Fridericiani) and subsequently out of the ALR (Allgemeines Landrecht für die Preußischen Staaten), in force as of $1794 .{ }^{21}$ During the creation of the BGB, ${ }^{22}$ which was in force from $1^{\text {st }}$ January 1900, the influence of the ALR (besides other reasons) caused the omission of the Falcidian portion from the BGB. ${ }^{23}$

\section{Czechoslovakia}

With the foundation of Czechoslovakia (28 ${ }^{\text {th }}$ November 1918) the question arose which legal system was to be valid in the new state. As a provisional solution, the existing legislation of particular areas remained in force under the so-called "reception norm." 24 As a result, the ABGB remained in force in Bohemia, Moravia and Silesia; and the Hungarian customary law in Slovakia and Ruthenia. ${ }^{25}$

A specific situation occurred in the Hlučín Region (Hlučinsko, Hultschiner Ländchen, Kraik hulczyński), now in the north-east of the Czech Republic. The Hlučín Region was part of the German Empire till 1918 (and of Germany during the Second World War), and the BGB was in force on this territory after the foundation of Czechoslovakia. This caused even bigger fragmentation of legislation on Czechoslovak

21 M. Hennig, op. cit., p. 38.

22 Law No. 21/1896 RGBl., Bürgerliches Gesetzbuch, (hereinafter referred to as "BGB").

23 M. Hennig, op. cit., p. 186.

24 Art. 2, Law No. 11/1918 Sb., o zřízení samostatného státu československého: Veškeré dosavadní zemské a řišské zákony a nařizení zůstávaji prozatím v platnosti (my emphasis, R.Č.). [All the existing provincial and imperial laws and regulations remain valid for the time being].

25 Die Entwicklung des Tschechischen Privatrechts, ed. L. VojÁčEK, K. Schelle, J. TAuChen, Brno 2011, p. 99. 
territory, that is why the ABGB applied in the Hlučín Region after 1920 as well. ${ }^{26}$ This change was not fundamental to the topic of this article, because - as already mentioned - the Falcidian portion was not included in either the BGB nor the ABGB. ${ }^{27}$

Even though the BGB was not applied in the Hlučín Region after 1920, remnants of the dualism of the former Austrian and Hungarian legislations still lingered in the Czechoslovakian legal system. Thus work on a new civil code was commenced. Its main aim was to unify Czechoslovakian civil law, and as regards its content, only slight modifications of the ABGB were proposed. ${ }^{28}$ There were no changes in relation to the Falcidian portion. By the way, compared to the ABGB, the draft contained mostly stylistic changes. This draft, called 1937 Draft, ${ }^{29}$ was not enacted due to the imminent outbreak of the Second World War.

It was not until the Civil Code of $1950^{30}$ was passed that civil law in Czechoslovakia was unified. As this code was drafted in the Communist period, there were efforts to suppress any influences of Roman law. Therefore it is surprising that the Falcidian portion was included in this code, even though in a somewhat modified form. The legal regulation of legacies (and the law of succession in general) was considerably simplified in the Civil Code of 1950, as compared with the ABGB. The fact that some regulations of the Civil Code of 1950 were closer to Roman law than their counterparts in the ABGB seems even more surprising. In this case, it was more a question of a sporadic

26 Ibidem, p. 99.

${ }^{27}$ For the use of the BGB and the Falcidian portion on Czechoslovakian territory in more detail see R. ČERNOCH, Falcidiánská kvarta a BGB, [in:] I. česko-slovenské setkáni doktorských studentů a postdoktorandi̊ oboru právni historie a řimského práva, ed. L. VoJÁčEK, J. TAUCHEN, Brno 2013, p. 57-67.

28 Di̊vodová zpráva - konsolidovaná verze. [online]. [cit. 2013-11-29]. s. 17. Accesible via: <http://obcanskyzakonik.justice.cz/tinymce-storage/files/Duvodovazprava-NOZ-konsolidovana-verze.pdf $>$ (hereinafter referred to as "Explanatory Note").

29 Tisk 844. Vládní návrh zákona, kterým se vydává občanský zákoník [online]. [cit. 2013-11-29]. Accessible via: <http://www.psp.cz/eknih/1935ns/ps/tisky/t0844_01. $\mathrm{htm}>$ (hereinafter referred to as "the Draft of 1937").

30 Law No. 141/1950 Sb., občanský zákoník (hereinafter referred to as "the Civil Code of 1950"). 
instance of provisions based on Roman which happened to correspond to the ideological interests of the time, mainly to the restriction of a testator's capacity to act mortis causa. ${ }^{31}$

So the Civil Code of 1950 still contained the institution of the legacy, but provisions regulating the position of an heir were appropriately applied to the legatee, ${ }^{32}$ except for liability for a testator's obligations if the value of a bequest was infinitesimal in comparison with the estate.

A passage which is much more interesting for the purpose of this article is the end of the provision's second sentence, because in fact it is the Falcidian portion, however its proportion is the reverse of the ratio laid down in Roman law, because the quarter was not the part reserved for the heir, but the maximum possible amount of all the legacies. Another difference was that if the determined amount was surpassed, there was not a proportional reduction of the legacies, as could be expected, but the legatee was considered an heir. ${ }^{33}$

The Civil Code of 1964, in force till the end of 2013, simplified the legal regulation of the law of succession again. Legacies were cancelled and deathbed gifts were banned. The Civil Code of 1964

31 P. SAlÁK, Odkaz - římskoprávní institut ve světle českého práva 20. stol, [in:] Dny práva - 2010 - Days of Law. [online]: Brno 2010 [cit: 2011-12-04]: Dostupné z: <http://www.law.muni.cz/sborniky/dny_prava_2010/files/sbornik.html>, p. 1626.

$32 \S 537$, the Civil Code of 1950: Byla-li někomu zůstavena peněžitá částka nebo jiná movitá věc jako odkaz, platí o odkazu a o odkazovnikovi přiměr eně ustanovení o dědictvi a o dédici. Odkazovník však neodpovídá za závazky zůstavitelovy, ani za náklady jeho pohřbu, byla-li odkazovníkovi zůstavena věc, jejiž cena je v poměru $k$ ceně zanechaného majetku jen nepatrná, a jestliže souhrn odkazů nečiní více ně̌ čtvrtinu toho, co zbude ze zanechaného majetku po odečteni dluhù (my emphasis, R.Č.). [If an amount of money or other movable thing is bequeathed as a legacy, the appropriate regulation of an inheritance and an heir is applied to the legacy and the legatee. However, the legatee is not liable for the testator's obligations, nor the expenses of his funeral, if the value of the thing bequeathed to the legatee is only infinitesimal in relation to the value of the estate, and if the sum of the legacies does not amount to more than a quarter of what is left of the estate after the deduction of debts].

33 R. ČERnOCH, Dédické právo ve Středním kodexu aneb vytlačování práva ř́mského právem ř́mským, [in:] Pocta Karlu Schellemu $k$ 60. narozeninám, ed. M. FRÝDEK, J.TAUCHEN, Ostrava 2012, p. 215. 
does not contain any mortis causa institution other than a testament; and thereby does not consider the Falcidian portion at all.

\section{The Czech Republic}

After the establishment of the Czech Republic the Civil Code of 1964 remained in force, albeit a need for a new Civil Code was obvious. Work on a new civil code became more intensive in recent years, resulting in the Civil Code of 2012, coming in force on $1^{\text {st }}$ January 2014. The ideological viewpoints of the Civil Code of 2012 have been inspired primarily by the 1937 Draft, but also by the BGB and other (especially European) civil codes. ${ }^{34}$

For the purpose of this article, $\S 1598$ of the Civil Code of 2012 is interesting, because it embodies the Falcidian portion in a manner principally corresponding to Roman law. ${ }^{35}$ Therefore, if an inheritance is overburdened with legacies, their amount must not surpass three quarters of the inheritance, otherwise a proportional reduction of the legacies occurs, so that a quarter of the inheritance is reserved for the heir.

In this context, it is necessary to emphasise that in $\S 1598$, it is obviously not a mere random concordance of the provision with Roman law, because the explanatory note ${ }^{36}$ to the Civil Code of 2012 explicitly states (in Latin) that the basis of $\S 1598$ is

\footnotetext{
34 Explanatory Note, s. 17.

35 § 1598, the Civil Code of 2012: Každému z dědic ů musi zůs tat z hodnoty dědictví a lespoň čtvrtina odkazy nezatížená. Zatíži-li zưstavitel dédice více, má dédic právo na poměrné zkrácení odkazu (my emphasis, R.Č.). [At least a quarter not burdened with legacies from the value of the estate has to be reserved for each of the heirs. If the testator burdens the heir more, the heir is entitled to a proportional reduction of the legacy].

36 In the Czech Republic, a sponsor of a bill presents an explanatory note (Dưvodová zpráva) along with the law, explaining the purpose of the proposed law and its individual provisions. The explanatory note is not a part of the law; however, it is an important aid for the interpretation of its provisions.
} 
quarta Falcidia. ${ }^{37}$ An inspiration by Roman law can be concluded without any doubt from the Latin formulation, because the use of Latin in the law of the Czech Republic is very sporadic. The situation in this respect is actually almost the same as in Poland. ${ }^{38}$ Czech universities were closed during the Second World War, ${ }^{39}$ and under Communism there were efforts to eliminate the influence of Roman law from the legal order. Since 1989 Latin terms have been appearing from time to time in judicial decisions and legal documents, particularly the same proverbs which are used in Polish judicial and legal documents. ${ }^{40}$

However, the use of a Latin term in an explanatory note to a law is something extraordinary. Therefore, the legislator's use of the term quarta Falcidia indicates that the provision has been inspired by Roman law.

\section{Conclusion}

Ever since $40 \mathrm{BC}$ the Falcidian portion has been a means of protecting an heir against the overburdening an estate with legacies; this regulation was later extended to other mortis causa institutions. Subsequently the Falcidian portion became part of the legal order of the Holy Roman Empire. It was adopted by some modern civil codes during their preparation, but not by the codes which were valid on the territory of the present-day Czech Republic (the ABGB, the BGB to a limited extent). The Falcidian portion was included in the

37 Explanatory Note, s. 398.

38 M. JoŃCA, Legal Latin in the Polish courts - between noble ideology and bitter practice, [in:] Diritto romano e attualità. La terminologia giuridica nel diritto processuale romano e moderno: La decisione giudiziaria e sua esecuzione. Atti del VII seminario internazionale in onore di Hans Ankum, ed. K. Stloukalová, J. ŠEJdL, Praga 2013, p. 17.

39 The Faculty's History [online]. [cit: 2013-11-27]: Accessible via: <http://www. law.muni.cz/content/en/o-fakulte/prezentace-fakulty/z-historie-fakulty/>.

40 M. JoŃCA, op. cit., p. 19. 
Civil Code of 1950, but in a reversed proportion and if the legacies surpassed a quarter of the estate they were not reduced, but the legatee was considered an heir. The Civil Code of 1964, in force till the end of 2013, cancelled the institution of the legacy and thus the modified provision of the Falcidian portion, too.

However, in the Civil Code of 2012, in force since $1^{\text {st }}$ January 2014, the Falcidian portion appears in a form corresponding to Roman law. This fact is quite interesting, because now for the first time this provision based on Roman law has become part of the legal order on the territory of the Czech Republic. This shows that the reception of Roman law is not merely a thing of the past, but that it can occur nowadays as well.

\section{KWARTA FAlCydyjSKa nA TERYTORIUM RePubliki CZESKIEJ}

\section{Streszczenie}

Artykuł dotyczy wprowadzenie kwarty falcydyjskiej do kodeksów prawa cywilnego obowiązujących na terytorium Republiki Czeskiej. Chociaż kwarta falcydyjska stanowiła element prawa (rzymskiego) stosowanego w Świętym Cesarstwie Rzymskim, nie stała się ona częścią niemieckich kodeksów cywilnych (austriackiego ABGB, niemieckiego BGB), które były stosowane na terenach, które obecnie należą do Republiki Czeskiej. Po powstaniu Czechosłowacji przygotowywano nowy kodeks cywilny, ale jego wprowadzenie uniemożliwił wybuch II wojny światowej. Celem tego kodeksu było nieznaczne zmienienie ABGB i kwarta falcydyjska nie została w nim uwzględniona.

W czasach komunizmu ABGB zostało zastąpione przez nowy kodeks cywilny z 1950 r., który, w dość zaskakujący sposób, wprowadził regulacje zainspirowane kwarta falcydyjską, ale kwarta ta dotyczyła najwyższej możliwej kwoty legatów, poza tym natomiast legatariusza uznawano za dziedzica. Tzw. socjalistyczny kodeks cywilny z 1964 r. (obowiązujący do końca 2013 r.) znacznie uprościł regulacje dotyczące prawa spadkowego i wykluczył przysporzenia mortis causa inne niż testamentowe, w związku z czym wykluczone było jakiekolwiek 
uregulowanie kwarty falcydyjskiej. Kodeks cywilny z 2012 r., który wszedł w życie 1 stycznia 2014 r. jest pierwszym kodeksem na terytorium Republiki Czeskiej, który wprowadza kwartę falcydyjską w sposób zasadniczo zgodny z prawem rzymskim.

Keywords: ABGB (Austrian Civil Code), BGB (German Civil Code), Czechoslovak Civil Code of 1950, Czech Civil Code of 2012, Falcidian Portion (quarta Falcidia), Law of Succession, Roman Law.

Słowa kluczowe: ABGB (Austriacki kodeks cywilny), BGB (Niemicki kodeks cywilny), Czechosłowacki kodeks cywilny z 1950 r., Czeski kodeks cywilny z 2012 r., kwarta falcydyjska (quarta Falcidia), prawo spadkowe, prawo rzymskie. 